UDC 339.95:330.22](438)

JEL F 200, F 210, O 520

10.26906/eip.2019.1(72).1439

\title{
FEATURES OF INVESTMENT ACTIVITY IN THE NATIONAL ECONOMY OF POLAND
}

\author{
Liudmyla Ryneiska*, PhD, Associate Professor \\ Vladyslav Zhytnyk \\ Poltava National Technical Yuri Kondratyuk University. \\ Valentyna Perederii, \\ Deputy Director of the PE "YAVIS XXI"
}

*ORSID: 0000-0002-3288-1127

(C) Ryneiska L., 2019.

(C) Zhytnyk V., 2019.

(C) Perederii V., 2019.

Стаття отримана редакиією 15.02 .2019 р.

The article was received by editorial board on 15.02.2019

Introduction. Modern globalization contributes to the revitalization of all actors of the world economy, including national economies. But the effective development of the economy of each state requires investment. At the same time, the investment process is quite complex and depends on many factors. The investment complexity and its necessity for the economic development of countries, makes the issue of the investment activities organization. In this regard, the study of the positive experience of investment activities in certain countries (for example, in Poland) has a scientific and practical interest.

Review of recent researches and publications. The investment activity, also in Poland, was investigated by many scientists. M. H. Dolhopolov and V.F. Savchenko analyzed the results of the economic reform in Poland, including its investment component. A. O. Charkina, and K. S. Proskuriakova investigated the administrative reform in Poland and the creation of a legislative framework in the field of finance publicity and the fight against corruption, which contributed to improving the investment activities efficiency. V.V. Tkach and S.M. Sokoteniuk, considered the rehabilitation of the Polish economy through the use of foreign loans. N. I. Isaieva studied strategic planning of the Polish regional development. $\mathrm{Yu}$. Kindzerskyi analyzed the stimulation of production and inter-regional alignment of the Polish economy through special economic zones. O. Dyba, Yu. Herneho and O.O. Kurchenko studied the experience of Poland in financing its innovative business, including start-ups. But given the importance and complexity of investing in the national economy, this problem requires further research.

Problem formulation. Using analytical, comparative, statistical methods of research to analyze the features of investment activity in the national economy of Poland, namely: ways of using the investment component in the process of reforming the economy and its further development; the introduction of effective tools to stimulate domestic and foreign investment in order to develop the economy of the country and its regions; priority investment of innovative business.

Main research material and results. Poland is one of the countries of the former socialist camp, which has demonstrated an example of effective investment activity. Back in September 1989, when the Polish economy was in a state of deep economic crisis, a plan of large-scale reforms was developed. It should have contributed to the rapid transition of the Polish economy from an outdated and inefficient system of centralized planning to market relations (the so-called "shock therapy"). The national economy development was urgently in need of investment and therefore among the main areas of reform were reforms directly related to investment activities [1, p. 84-85; 2]:

- The government must reform the investment policy: to provide tax incentives and simplified licensing to foreign investors. As a result, restrictions on the investment volume and export of profits 
abroad have disappeared. The volume of direct foreign investments increased from 4.3 billion dollars at the end of 1994 to 20.6 billion dollars in 1997, and in 2013 it was amounted to about 180 billion dollars;

- Efficient distribution of EU funds: most of the money was directed to support small and medium-sized businesses, educational programs and loans for entrepreneurs. As a result, today half of Poland's GDP is provided by small and medium-sized businesses.

The positive results of Poland's economic development were made possible largely by the improvement of its investment policy by the government. Thus, in Poland there is a legally established list of investment promotion tools, which include: state financial support for investments in priority sectors; grant support for projects at the expense of structural funds of the European Union, mainly social, infrastructure, research, through the implementation of the government's so-called operational programs (for example, "Innovative economy", "Development of Eastern Poland"); local taxes exemption; subsidies for the employment of unemployed, etc. Every entrepreneur can simultaneously use various forms of state aid, but the total amount may not exceed the maximum allowable amount established by the state for a particular region [3, p. $103-$ $110 ; 4$, p. $40-44]$.

Investment promotion tools were actively used for the development of Poland and its regions. The strategic goal of regional policy in Poland was the investment development of regions of its potential to boost the economy of the whole country [5]. The Act "On Principles of Supporting Regional Development" of 12.05.2000 defines support (including financial) for regional development as a territorially directed sphere of activity of the government and its administration. Support of regional development takes into account the requirements related to the need to strengthen the economic unity and territorial integrity of Poland as a single state [6].

Financial support for regional development is carried out on the basis of the "National strategy for Regional Development for 2010 - 2020" and is aimed at the implementation of tasks: the development of entrepreneurship, especially small and medium-sized; economic innovations, technology transfer; restructuring of selected sectors of the economy; creation of new jobs; investment in the field of technical and transport infrastructure [6, 7].

Financing of regional development support is provided through the implementation of operational programs and is carried out both at the expense of the EU funds and the budgets of Poland on the basis of contracts:

- operational Program "Innovative economy" (for 2014 - 2020), which finances research, development and innovation. 8.3 billion euros from European funds have been allocated for its implementation;

- operational Program "Infrastructure and Environment 2014 - 2020 "(27.9 billion euros from the EU) has become a source of funds for transport infrastructure, energy, low-carbon economy, etc;

-operational Program "Digital Poland" provides almost 2.2 billion euros from the EU budget for broadband Internet, e-administration and increase of digital competencies of the community;

-operational Program "Development of Eastern Poland" (financing of 2 billion euros from the EU funds). The funds are intended to finance entrepreneurship and innovation, public transport and communications, rail transport in the cities of Eastern Poland;

-the "Technical Assistance" Program provides for the financing more than 700 million euros from the EU budget for development of the system of implementing EU funds in Poland (training of beneficiaries and staff of the institutions that implement funds) [8, p. 69].

Special economic zones (SEZ) are another legally established tool for stimulating investment in Poland. They are administratively allocated parts of the territory of Poland, intended to conduct economic activity in them by business entities to preferential conditions in comparison with other territories. Entrepreneurs who have expressed a desire to start economic activity in the SEZ and received the appropriate permission to conduct it, are provided with state assistance in the form of such benefits as exemption from income tax (for legal entities), income tax (for individuals), local taxes and fees, in particular land tax and real estate tax, the establishment of preferential prices for 
the purchase of land with a fully prepared infrastructure for production, the provision of free administrative services for registration and business [9, p. 46;10, p. 90].

The operation of the SEZ in Poland is governed by such basic legislative acts as the Act "On special economic zones" of October 20, 1994 and the Act "On the procedure for granting state aid" of 30 April $2004[11,12]$. In addition, the activities of each of the zones are regulated by separate orders of the Council of Ministers and the Ministry of Economy of the Republic of Poland [9, $p$. 46]. According to the legislation, the purpose of creating a SEZ is to accelerate the economic development of the territory in which it is located, through legally defined priority economic activities, creation of new products and technologies and their further introduction in the economy, development of exports, improving the competitiveness of goods and services; restoration of the use of existing industrial capacities and infrastructure; creation of new jobs; development of natural resources in compliance with the principles of environmental balance. SEZs are used primarily as a tool for regional alignment, stimulating the development of backward regions, in which, according to the EU regulations on the provision of regional aid, the volume of GDP per capita does not exceed $75 \%$ of the average level in the country [13, p. 40].

Most of the direct foreign investments of the leading world corporations coming to Poland and sent to the manufacturing sector are located exactly in the territories of SEZs [9, p. 46]. Since the beginning of the operation of the zones and by the end of 2013, a total of 27 billion dollars had been invested into the Polish SEZs. In the years 2003 - 2013, the total volume of accumulated investments increased more than 5 times [9, p. 48; 14, p. 38]. Polish entrepreneurs are the largest investors in the SEZs of their country, their share in 2013 amounted to a fifth of all investments $(19.19 \%)$ of all funds in the SEZs, which indicates the attractiveness of the zones primarily for domestic business. The five largest foreign investor countries from other countries in 2013 included Germany (15.6\%), USA (12.1\%), Netherlands (11.56\%), Italy (8.45\%) and Japan $(7.25 \%)$, which accounted for more than half (54.9\%) of all funds invested in Poland's SEZs [ 14, p.18].

In view of the high competitiveness of the innovative business itself, investors, including foreign ones, prefer to invest their money directly into its enterprises. Most of them are small and medium-sized enterprises. In Poland, within the framework of the government program "Entrepreneurship in the first place", were formed criteria for the differentiation of small and medium-sized enterprises, which allowed them to purposefully stimulate their innovative development [15, p. 11]. These include, in particular, and start-ups (from the English. "start-up" - to run), that is, companies with new and bold projects that are created to capitalize income. Following the world-wide experience in the development of start-ups, the government of Poland has also taken a number of measures: the creation of an appropriate legal and regulatory framework; commercialization of innovative technologies and solutions is one of the priorities of state development "Strategy 2020", adopted by the Polish Council in 2012; opening a start-up takes only one day; the e-Commerce Directive has been fully implemented in the country; encouraging students/graduates to create an enterprise; creation of credit guarantees for bank loans for start-ups at the national level [16, p. 25, 29].

The expansion of innovative business opportunities served as the basis for its transition to a qualitatively new level. This has raised the interest of international organizations and foreign investors in participating in Polish innovation development programs. During 2010 - 2013, the share of foreign investment amounted to about 7\% among other sources of financing innovative development [15, p. 12;17].

It should be emphasized that the efficient use of investments directed at production (primarily in innovation) and contributed to the development of the national economy of Poland, was largely due to the fight against bureaucracy and corruption of the state apparatus, which had access to the distribution of these investments. In Poland, an administrative reform was carried out, the principles of which were laid down in the traditions of European civilization, among which were transparency, openness and accountability. In this direction the Polish Parliament has adopted and implemented full range of laws in the field of finance publicity and the fight against corruption [18, p. 96; 19, p. 70]. 
Conclusions. The scientific novelty of the study results is that the investment activity in the Polish economy is considered as a complex multilateral phenomenon, as well as its specific features inherent in this country. Scientific and practical importance is the analysis of the components of this complex, which are interdependent and complement each other, thus creating an effective system of investment activity in Poland:

- formation of the legal framework for the investment activity organization;

- administrative reform and adoption of a set of laws in the field of finance publicity and the fight against corruption of the state apparatus, which had access to the distribution of investments. This contributed to the targeted use of investments for the development of the Polish economy;

- development and implementation of the "National Strategy for Regional Development for 2010 2020", an integral part of which is the investment in the development of the Polish regions in order to boost the economy of the whole country;

- creation of a favorable investment climate in the country by the government;

- development and use of effective tools for stimulating investment activity (Special Economic Zones, Operational Programs (for example, "Development of Eastern Poland", "Innovative Economy", etc.), grants of the European Union, the establishment of preferential taxes, etc);

- priority investment of innovative business (especially small and medium-sized businesses, including start-ups) as the most perspective and important for economic development of Poland.

The prospect of further research development in the field of investment is expedient to consider the development of proposals for the organization of effective investment activity of a particular state (including Ukraine):

- improvement of the legal framework of investment activity and strict control over its observance;

- creation of a favorable investment climate in order to receive both domestic and foreign investments from foreign businessmen, countries and international organizations;

- financing research of international experience in the field of investment in research institutes; development on the basis of this experience and taking into account the peculiarities of the national economy development the development strategy of the national economy and its investment component;

-identification and implementation of effective investment promotion tools such as Special Economic Zones, Start-ups (which have not yet been widely disseminated in Ukraine);

- expansion of innovative business and its priority investment.

\section{REFERENCE:}

1. Tkach, V. \& Sokotenyuk, S. (2016). Rehabilitation of Ukrainian economy by using foreign loans in case of Greece and Poland, Investytsii: praktyka ta dosvid (Investments: practice and experience), vol. 6 , pp. $81-86$.

2. Savchenko, V. F. \& Dolhopolov V. F., (2014). "Shock therapy": Polish achievements, miscalculations and failures of Ukrainian reformers, Visnyk Chernihivskoho derzhavnoho tekhnolohichnoho universytetu. Seriia: Ekonomichni nauky (The Herald of Chernihiv State Technological University. Series: Economic Sciences), vol. 3, pp. $14-20$.

3. Investor's guide: Poland. Business rules / Polish Information and Foreign Investment Agency. - Warsaw, 2010. - $188 \mathrm{p}$.

4. Legal and tax rules for doing business in Poland / Polish Information and Foreign Investment Agency. - Warsaw, 2004. - 55 p.

5. National Strategy for Regional Development 2010-2020: Regions, Cities, Rural Areas. Warsaw: Ministry of Regional Development, 2009 [Electronic resource]. - Access: http://www.mrr.gov.pl/aktualnosci/rozwoj_regionalny/Documents/KSRR_09_09_09_kor_red_stat. pdf

6. The Act on the Principles of Support for Regional Development of 12 May 2000 [Electronic resource]. - Access: http://www.sejm.gov.pl

7. SOCIO-ECONOMIC DEVELOPMENT STRATEGY OF EASTERN POLAND UNTIL 
2020

[Electronic

resource].

Access:

http://www.mr.gov.pl/media/3372/Strategia_PW_11_07_2013_zmn.pdf

8. Isaieva, N. (2016). Strategic planning of regional development of Poland// Інвестиції: практика та досвід, Investytsii: praktyka ta dosvid (Investments: practice and experience), vol. 11, pp. 67 -70 .

9. Kindzerskyi, Yu. (2015), Stimulation of production and interregional alignment by means of special economic zones: experience of Poland in a context of a euro-integration course of Ukraine, Ekonomist (Economist), vol. 6, pp. 46 - 50.

10. Poland is your economic partner / Ministry of Economy of the Republic of Poland; Institute for Market, Consumption and Business Cycles Research. - Warsaw, 2008. - 205 p.

11. Act of October 20, 1994 "On Special Economic Zones" // Herald of the Law of the Republic of Poland, 1994. - vol. 123. - pos. 600.

12. Act of 30 April 2004 "On proceedings in matters concerning state aid" // Herald of the Law of the Republic of Poland, 2004. - vol. 123. - pos. 1291.

13. Legal regulation of state aid in the European Union and Ukraine. Ways of adaptation of the legislation of Ukraine / O. V. Nivievskyi, S. V. Taran, N. I. Leshchenko; Ministry of Justice of Ukraine, Kyiv, 2012, 179 p.

14. Information on the implementation of the Act on Special Economic Zones (December 31, 2013) / Ministry of Economy, Warsaw, 2014, 39 p.

15. Dyba, O. \& Herneho, Yu. (2015). Financing of innovative development: the experience of Poland and recommendations for Ukraine, Ekonomist (Economist), vol. 11, pp. $11-14$.

16. Kurchenko, O. O. (2015). State support for start-ups: Polish experience, lessons for Ukraine, Problemy nauky (Problems of science), vol. 12, pp. 25 - 30.

17. Statistical Yearbook of Industry Poland 2012/ [President of editorial board Janusch Witkowski]. The central statistical office of Poland, Warsaw, 2013, 517 p.

18. Charkina, A. (2016). Principles of public service in European Union countries (for example Poland and Germany), Investytsii: praktyka ta dosvid. (Investments: practice and experience), vol. 16, pp. $95-99$.

19. Proskuriakova, K. S. (2014). European standards of public service: experience of the Polish Republic, Visnyk Kyivskoho natsionalnoho universytetu imeni Tarasa Shevchenka. Derzhavne upravlinnia (The Herald of Kyiv Taras Shevchenko National University. Public administration), vol. 1, pp. $69-72$.

UDC 339.95:330.22](438)

JEL F 200, F 210, O 520

Ринейська Людмила Сергіївна, кандидат економічних наук, доцент. Житник Владислав Олександрович. Полтавський національний технічний університет імені Юрія Кондратюка. Передерій Валентина Анатоліївна, заступник директора ПП «ЯВIC XXI», м. Полтава. Особливості інвестиційної діяльності в національній економіці Польщі. Обгрунтовано думку, що сталий розвиток економіки будь-якої країни можливий лише за умови іï ефективного інвестування. Успішність інвестиційної діяльності залежить від багатьох факторів, у тому числі від об'єктивної оцінки стану національної економіки та її потенціалу, правильного визначення пріоритетів інвестування та вибору ефективних механізмів його реалізації. Не менш важливим є питання співвідношення внутрішніх та іноземних інвестицій, необхідних для економічного розвитку окремо взятої країни.

Розглянуто особливості інвестиційної діяльності в національній економіці Польщі. За досить короткий проміжок часу після виходу 3 колишнього соціалістичного табору й отримання незалежності ця держава сформувала ринкову економіку та, активно використовуючи внутрішні й іноземні інвестиції, значно підвищила іiі конкурентоспроможність. Проаналізовано позитивний досвід інвестування у реформуванні економіки Польщі та ії подальшому розвиткові.

Досліджено стратегічно важливу тенденцію економічної політики польського уряду щодо піднесення національної економіки завдяки розвитку потенціалу регіонів країни, проаналізовано значення інвестування у цьому процесі. Одним із напрямів державної економічної політики стало стимулювання виробництва та міжрегіональне вирівнювання 
економіки Польщі через спеціальні економічні зони (СЕ3). Обгрунтовано думку, що СЕ3 стали одним 3 ефективних інструментів стимулювання як внутрішнього, так і іноземного інвестування.

Особливу увагу приділено інноваційному спрямуванню економіки Польщі. Обгрунтовано необхідність пріоритетного інвестування інноваційного бізнесу, у тому числі стартапів.

У результаті проведеного дослідження зроблено висновки стосовно особливостей розвитку інвестиційної діяльності в економіці Польщі й висловлено пропозиції щодо заходів поліпшення інвестиційного процесу, що сприятиме ефективному розвиткові національних економік (у тому числі України).

Ключові слова: інвестиції, інвестування національної економіки, спеціальні економічні зони, інновації, стартапи.

$$
\text { УДК 339.95:330.22](438) }
$$

JEL F 200, F 210, O 520

Ryneiska Liudmyla, PhD, Associate Professor of the Department of International Economics and Marketing. Zhytnyk Vladyslav . Poltava National Technical Yuri Kondratyuk University. Perederii Valentyna, Deputy Director of the PE "YAVIS XXI", Poltava. Features of investment activity in the national economy of Poland. The features of investment activity in the national economy of Poland are considered. The role of investments in reforming the Polish economy and its further development is shown. The necessity of priority investment of innovative business is proved. Measures to improve investment activity for the national economy development are identified.

Keywords: investment, national economy investment, special economic zones, innovations, startups.

$$
\text { УДК 339.95:330.22](438) }
$$

JEL F 200, F 210, O 520

Рынейская Людмила Сергеевна, кандидат экономических наук, доцент. Житник Владислав Александрович. Полтавский национальный технический университет имени Юрия Кондратюка. Передерий Валентина Анатольевна, заместитель директора ЧП «ЯВИС XXI». Особенности инвестиционной деятельности в национальной экономике Польши. Обоснована мысль о том, что стабильное развитие экономики какой-либо страны возможно лишь при условии ее эффективного инвестирования. Рассмотрены особенности инвестиционной деятельности в национальной экономике Польши. В течение достаточно короткого времени после выхода из бывшего социалистического лагеря и получения независимости эта страна сформировала рыночную экономику и, активно используя внугренние и иностранные инвестиции, значительно повысила еe конкурентоспособность. Проанализирован положительный опыт инвестирования в реформировании экономики Польши и ее дальнейшем развитии. Исследованы стратегически важная тенденция экономической политики польского правительства относительно усиления национальной экономики благодаря развитию потенциала регионов страны, проанализировано значение инвестирования в этом процессе. Одним из направлений государственной экономической политики стало стимулирование производства и межрегиональное выравнивание экономики Польши благодаря специальным экономическим зонам (СЭЗ). Обоснована мысль о том, что СЭЗ стали одним из эффективных инструментов стимулирования как внугреннего, так и иностранного инвестирования. Особое внимание уделено инновационному направлению экономики Польши. В результате проведенного исследования были сделаны выводы об особенностях развития инвестиционной деятельности в экономике Польши и высказываются предложения относительно мероприятий, активизирующих инвестиционный процесс, что будет способствовать эффективному развитию национальных экономик (в том числе и Украины).

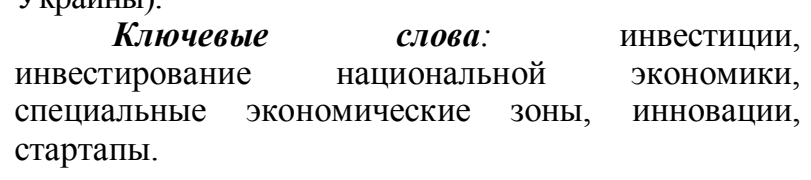

